\title{
Bricolageliturgie: Liturgical Studies Revisited
}

Marcel Barnard ${ }^{1}$

(Protestantse Theologische Universiteit, Utrecht)

\section{ABSTRACT}

\section{Bricolage liturgy: Liturgical Studies revisited}

This article examines a fifth trend, complementary to the four identified in a previous article, in contemporary liturgy visible in churches in the Netherlands as well as South Africa. Drawing on the specific case in the Netherlands of a service in which a minister was ordained, the tendency to mix liturgies is highlighted. This "cut-andpaste" liturgy can be described as "bricolage liturgy". The term "bricolage" is not new: its use by Claude Lévi-Strauss and Jacques Derrida is investigated in order to better apply the term to liturgy. Bricolage liturgy is a-centrical and a-typical. Jesus Christ, then, is the point of departure for understanding the rituals of liturgy, without restricting a service to a set pattern.

\section{BRICOLAGELITURGIE OP EEN ZONDAGMORGEN IN EEN NEDERLANDSE DORPSKERK}

Bij wijze van casus open ik dit artikel met een korte beschrijving van de kerkdienst die ik, min of meer toevallig, bezocht in de zondag van de week waarin ik dit artikel moest schrijven. Die beschrijving rust louter en alleen op mijn waarneming van de dienst vanuit een deelnemersperspectief. Alle andere perspectieven blijven buiten beschouwing. Het was ergens in een mooie middeleeuwse dorpskerk in het midden van het land. De gemeente die er samenkomt, behoort tot de Protestantse Kerk in Nederland. Een jonge vrouw (opgeleid in Utrecht en Pretoria) wordt door haar vader bevestigd in het ambt van predikant en de gemeente krijgt daarmee een nieuwe voorganger. We zingen psalmen en gezangen uit de officiële liedbundel van de kerk, het Liedboek voor de Kerken, maar ook liederen uit de bundel Opwekking, de Youth for Christ Zangbundel en uit de proefbundel Tussentijds. De zang wordt begeleid door orgel en door de jongeren praiseband Bandjamin (slagwerk, piano, klarinet, gitaar, zangeressen). De stijlverschillen lopen in het oog, maar lijken, althans op het eerste gezicht, de gemeenteleden niet erg te deren.

1 Navorsingsgenoot van prof C J A Vos, Departement Praktiese Teologie, Fakulteit Teologie, Universiteit van Pretoria. 
Liederen uit het Liedboek en Tussentijds vertegenwoordigen een typisch kerkelijke en poëtische taal en idem muziekidioom. De liederen uit de andere bundels zijn eenvoudiger van taal, al is die taal in drie gevallen niet het Nederlands maar het Engels. Muzikaal gesproken zijn ze uitdrukking van een populair idioom. Verder valt op dat het persoonlijke een sterk accent krijgt in de dienst. Anders dan men misschien zou verwachten bij een ambtsbevestiging, wordt de kerk als breder geheel dan deze plaatselijke gemeente slechts beperkt zichtbaar. De ambtsbevestiging is toegespitst op deze vrouw die haar weg naar het ambt gevonden heeft, dochter van deze vader. De familie van de nieuwe predikant zit op de eerste rij, de predikanten die aan de handoplegging deelnemen op de tweede. Deze predikanten zijn twee andere pastores loci en drie predikanten (waaronder de auteur van dit artikel) die op een of andere manier een rol hadden gespeeld in de weg van de te bevestigen kandidaat op haar weg naar het ambt. Vertegenwoordigers van hogere vergaderingen ontbraken althans zichtbaar in de dienst. Vermeld moet nog worden dat de vader predikant is in het klassiekgereformeerde deel van de kerk waar vrouwelijke predikanten allerminst als vanzelfsprekend worden gezien. Het bevestigingsformulier dat gelezen wordt komt uit het einde van de twintigste eeuw, de vragen van de belofte zijn enigszins aangepaste moderne vragen uit de orde die het Dienstboek van de kerk aanreikt (Dienstboek 243v.; Barnard 2007a:243v.). De nieuw bevestigde predikant trekt pas, anders dan het Dienstboek van de kerk aangeeft, nadat zij bevestigd is haar (zwarte) toga (met rode stola) aan. Tenslotte viel op dat de stijl van de dienst, maar zeker ook van voorgaan, vooral van de nieuw bevestigde predikant, informeel, spontaan en goedlachs, en daarmee: overtuigend was.

De beschreven kerkdienst past niet in de traditionele sjablonen van klassiek-gereformeerd of oecumenisch-protestants, en ook niet in het (althans in Europa) nieuwere van praise and worship. Er is sprake van bricolage-liturgie. In ieder geval de voorgangers passen ook niet meer in de klassieke 'hokjes'; wel zijn er liturgisch gesproken rudimenten aanwijsbaar van voormalige kerkelijke modaliteiten. Ook de muzikale en talige stijlen vormen een mix, variërend van de kerkelijke muziekstijl van de officiële liedbundel tot het populaire idioom. Tenslotte is er het sterke persoonlijke element, dat gepaard gaat met een informele stijl, waarvoor de - in dit geval: - plechtige ambtsbevestiging plaats heeft moeten maken. 
De kerk in haar bovenplaatselijke gestalte en de predikant als bovenplaatselijke figuur komen nauwelijks in beeld.

De liturgie in deze dienst is niet traditioneel en voltrekt zich maar in beperkte mate 'volgens het boekje'; de dienst is eerder te karakteriseren als levendig en ontspannen, dan als formeel en 'kerkelijk'.

\section{TENDENSEN IN EIGENTIJDSE LITURGIE}

De beschreven casus kan op veel manieren worden geanalyseerd. Ik wil de casus bespreken onder slechts één gezichtspunt, dat van de bricolage: liturgie als knip- en plakwerk, als knutselwerk. In dit artikel gebruiken we de casus exemplarisch om aan de hand van het bricolagebegrip te komen tot een programmatische aanduiding van nieuwe richtingen voor de liturgiewetenschap. Dit artikel is daarom exploratief van karakter. De casus wordt niet diepgaand geanalyseerd, maar ingezet om een dominante tendens in de liturgie aan te geven en de consequenties daarvan aan te duiden voor de wetenschap die de liturgie bestudeert, de Liturgical Studies. Zeven jaar geleden hield ik in Pretoria een lezing, later gepubliceerd in Zuid Afrika en in Nederland, waarin ik een overzicht gaf van tendensen die ik toentertijd in de liturgie waarnam (Barnard 2001; Barnard 2002). Ik noemde 1. een bloei aan rituelen en symbolen; 2. een interferentie van verschillende betekenissystemen; 3. een herstel van de eenheid van de domeinen kunst en liturgie, en 4. een (soms radicale) recontextualisering van de liturgie.

Met de eerste tendens doelde ik op een nieuw cultureel bewustzijn, onder referentie aan Clifford Geertz' bekende definitie van cultuur als "geordend systeem van betekenis en symbolen". Aandacht voor het symbolische en rituele karakter van de liturgie betekent voor de liturgiewetenschap een accent op een antropologische benadering en daarmee op de verworteling van de liturgie in de culturele en antropologische context van de actanten / participanten. Ronald Grimes heeft inmiddels aandacht gevraagd voor de notie "ritualizing", waarmee hij het opzettelijk ontwikkelen of uitvinden van riten in de marge van de gevestigde rituelen verstaat (Grimes 2000:29). Deze activiteit doet een beroep op de intuïtie en creativiteit, maar hoeft niet spontaan op instemming te rekenen. Martin Hoondert heeft juist ook in de 'marge' (over deze notie kom ik nog uitvoerig te spreken) van kerkelijke gemeenschappen dit proces waargenomen ten aanzien van kerkkoren die eigen repertoires 
ontwikkelen die een verbindende schakel tussen 'kernliturgie' en de cultuur vormen (Hoondert 2006:341v.; vgl. 322-334). In dit artikel zal blijken dat Hoondert ten onrechte vasthoudt aan de bipolariteit van kern en marge. De Bandjamins in de beschreven kerkdienst zouden een dergelijke groep in de 'marge' van de parochie kunnen vormen, al staat het repertoire van de groep mogelijk op de rand van geaccepteerd repertoire te worden. Dat verschillende betekenissystemen interfereren, blijkt uit de verschillende muziekrepertoires (grofweg: kerkelijk en populair), maar ook uit de verschillende kerkelijke stijlen die worden gehanteerd. Klassiekgereformeerde, oecumenisch-protestantse en praise and worshipstijlen lopen door elkaar heen. Ook de derde in 2001 genoemde tendens is nog volop actueel: een herstel van de eenheid van de domeinen kunst en liturgie. Juist eigentijdse kunst, in dit geval ("een afgeleide van” (Hoondert 2006:325v.)) de popmuziek, maakt haar entree in de kerkdienst. Dat is ook meteen een aanpassing van de kerkdienst aan de eigentijdse context en dus een aspect van de vierde tendens: recontextualisatie. Ook de nadruk op het persoonlijke, ten koste van het kerkelijk-institutionele, past in deze tendens.

Ik zou nu, zeven jaar later, in elk geval een vijfde tendens aan de vier genoemde toevoegen, namelijk de tendens liturgie vorm te geven door middel van bricolage. Deze tendensen zijn niet bedoeld om een definitieve beschrijving en analyse van geobserveerde liturgie te geven. Veeleer bedoelen ze attenderend en heuristisch te zijn. Het hybride en incidentele karakter van eigentijdse liturgie verhindert een definitieve ordening of karakterisering ervan. Genoemde tendensen zijn kwaliteiten van liturgie, die naast elkaar en doorheen elkaar voorkomen, de ene de ene keer meer dan de andere op een ander moment, kortom, in wisselende samenstelling en verhouding tot elkaar. Doordat de liturgische praktijk de traditionele verwachtingen en de klassieke ordeningsschema's voorbij is, volstaan algemene sjabloons niet meer om haar te beschrijven en analyseren. Dat heeft niet alleen consequenties voor de terminologie die in het praktisch-theologisch en liturgiewetenschappelijk discours wordt gebruikt, maar ook voor de wijze waarop termen worden gebruikt. Dit gebruik zal dus eerder heuristisch dan determinerend zal moeten zijn. 


\section{BRICOLAGE ALS NOTIE IN ETNOGRAFIE EN LITURGIEWETENSCHAP}

\subsection{Bricolage: primaire betekenis}

De notie bricolage wordt dikwijls in praktisch-theologische literatuur gebruikt om aan te geven hoe in de laatmoderniteit geloofsovertuiging, religie, spiritualiteit et cetera vorm krijgen. Mensen 'knutselen' hun eigen overtuiging of preek in elkaar, het is 'knip- en plakwerk'. Anders gezegd, religie en levensovertuiging worden samengesteld uit elementen van verschillende culturen, godsdiensten, filosofieën en overtuigingen. Ik heb zelf voorgesteld de notie ook met betrekking tot laat-moderne liturgie te gebruiken (Barnard 2006:75). Post wijst er, in navolging van Taft en Grimes op, dat liturgie-historisch gesproken feitelijk alle liturgie uit een samenstel van oorspronkelijk losse eenheden bestaat, ook de klassieke Romeinse, en dat de betekenis die aan het spreken over bricolages in de liturgie als laatmodern verschijnsel wordt toegekend, dus dient te worden gerelativeerd (Post 2007:79). In het Nederlands protestantse taalgebied is het klassieke $16^{\mathrm{e}}$ eeuwse avondmaalsformulier een voorbeeld van een dergelijke bricolage: het gaat terug op Calvijn, op à Lasco en Micron, en tenslotte ook nog op het Lutherse dienstboek van Württemberg 1553 (Lekkerkerker 1956:136-140).

De notie bricolage wordt nogal eens gebruikt met een negatieve ondertoon: als aanduiding namelijk van een weinig coherent, stabiel en substantieel geestelijk leven. Die negatieve waardering is mijns inziens' onnodig. Wel is het noodzakelijk om het bricolagebegrip te herijken. Ik doe dat door terug te keren naar de bron ervan. De antropoloog Claude Lévi-Strauss heeft de term in 1962 in de sociale wetenschappen geïntroduceerd. Vijf jaar later, in 1967, heeft Jacques Derrida de term verder geëxploreerd en ontwikkeld voor de geesteswetenschappen.

\subsection{Bricolage bij Claude Lévi-Strauss}

In zijn boek La pensée sauvage (1962) ontwikkelt Lévi-Strauss het polaire begrippenpaar "bricoleur" en "ingénieur", waarmee hij twee manieren van wetenschappelijke kennisverwerving aangeeft (LéviStrauss 1962:27v. = idem 1972:17). De werkwijze van bricoleur (knutselaar) en ingenieur (de geschoolde 'probleemoplosser') zijn te kenmerken als 'concreet' en 'conceptueel'. 
In één enkele alinea tekent Lévi-Strauss de bricoleur in vier nauw aan elkaar gerelateerde karakteristieken (Lévi-Strauss 1962:27 = idem 1972:17). Ten eerste lost een bricoleur problemen op met wat hij toevallig aan instrumenten voorhanden heeft. Hij kijkt niet eerst welke instrumenten hij nodig heeft om een probleem op te lossen, om zich die vervolgens te verwerven. Ten tweede bestaat de inhoud van zijn instrumententas uit wat daar inzit omdat hij dat toevallig heeft 'gevonden' of verzameld, omdat dat beschikbaar was. De bricoleur denkt niet in termen van projecten met daarbij behorende specifieke instrumentaria. In de derde plaats verzamelt de bricoleur instrumenten zonder dat hij van tevoren een specifiek gebruik ervan op het oog heeft. Hij verzamelt ze omdat ze misschien ooit van pas komen. Zijn "instrumental set" is "to be defined only by its potential use". Tenslotte kunnen zijn instrumenten worden ingezet voor vele gelijksoortige operaties.

Lévi-Strauss ontwikkelt het binaire begrippenpaar bricoleur ingenieur in zijn studie van mythen. Deze mythen kenschetst hij als "a kind of intellectual 'bricolage"” (Lévi-Strauss 1962, 26 = idem 1972, 17). Wanneer Lévi-Strauss spreekt van intellectuele bricolage, bedoelt hij dat allerminst depreciërend:

Like bricolage on the technical plane, mythical reflection can reach brilliant unforeseen results on the intellectual plane (Lévi-Strauss 1962:26 = idem 1972:17).

Mythen bestaan uit eenheden die op verschillende manieren kunnen worden gecombineerd. De combinatiemogelijkheden zijn niet eindeloos, maar beperkt, omdat de onderscheiden eenheden in de taal waaruit zij zijn genomen, al een bepaalde betekenis hebben, die hun inzet in nieuwe contexten beperkt. "Mythical thought" is bricolage; de bricolage heeft een "mytho-poetical nature". Derrida keert dat vijf jaar later om: bricolage is mythisch denken, maar er is geen andere wetenschap dan deze. Bovendien zal Derrida postuleren dat de hoeveelheid interpretaties en dus het aantal mogelijke betekenissen eindeloos is.

Voortdurend wijst Lévi-Strauss erop, dat de bricoleur en de ingenieur elkaar niet uitsluiten. Integendeel, ook in de ingenieur schuilt een bricoleur. De ingenieur heeft of ontwikkelt een instrumentarium dat voor een specifiek doel is bestemd en exclusief daarvoor bruikbaar is: elk materiaal vraagt om eigen instrumenten om te bewerken, en omdat ieder nieuw project weer om nieuwe 
instrumenten vraagt is zijn gereedschapskist in principe oneindig groot. Maar zijn middelen, macht en kennis zijn dat niet, en dan grijpt ook de ingenieur naar wat voorhanden is. Hij zal trouwens altijd eerst kijken wat voorhanden is, en eerdere ervaringen in zijn exploraties betrekken.

Zoals gezegd introduceert Lévi-Strauss de bricoleur en de ingenieur om twee manieren van wetenschappelijke kennisverwerving te beschrijven en analyseren. De noties worden vooral heuristisch ingezet, om een specifieke manier van kennisverwerving op het spoor te komen. $\mathrm{Zij}$ zijn dus geen aanduidingen voor de wijze waarop primitieve respectievelijk ontwikkelde samenlevingen zich kennis verwerven. Liever dan van primitieve (Lévi-Strauss 1962:355 = idem 1972:268; vgl. Van der Leeuw 1937; Hofstee 1991:132; Hofstee 1997:113-237; Barnard 2004a:91-100), en ontwikkelde wetenschap te spreken, benoemt hij de activiteit van de bricoleur en ingenieur als eerdere en latere wetenschap. Latere wetenschap is wetenschap in de zin waarin wij dat woord gewoonlijk gebruiken. Ten onrechte - zoals in Derrida's analyse zal blijken: de ingenieur is, althans in de geesteswetenschappen, een mythe (Derrida 1967:418 = idem 1978, 285).

\subsection{Bricolage bij Jacques Derrida}

Zoals bekend heeft Jacques Derrida de notie bricolage van LéviStrauss door een diepgaande analyse van diens tekst verder ontwikkeld (Derrida 1967 = idem 1978). Hij betrekt het begrip niet slechts op de mythe, maar op alle vertogen. Net als zojuist bij LéviStrauss, geef ik eerst weer kort de gedachtegang van Derrida weer.

In een eerste stap betrekt Derrida bricolage op de taal: wij betrekken onze concepten uit een taal die toevallig voorhanden is, uit een min of meer coherente erfenis. Ieder discours is een vorm van bricolage, ook het wetenschappelijke vertoog. De ingenieur in de zin waarin Lévi-Strauss daarover spreekt is een theologisch begrip, een mythe: geen mens kan met iedere vorm van bricolage breken en een totalitaire taal, syntaxis en lexicon ontwikkelen. Derrida onderstreept zodoende het 'mytho-poëtische' karakter van alle wetenschappelijke vertogen. Alle wetenschap is mythisch-poëtisch. Deze kritische reflectie op de taal van het wetenschappelijk discours geldt alle geesteswetenschappen, en dus, voeg ik toe, ook de praktische theologie, voor zover de Practices of Faith die zij onderzoekt delen 
in het socio-culturele discours. Dan volgt een kerncitaat in Derrida's analyse van het bricolagebegrip:

In effect, what appears most fascinating in this critical search for a new status of the discourse is the stated abandonment of all reference to a centre, to a subject, to a privileged reference, to an origin, or to an absolute archia (Derrida 1967:419 = idem 1978:286).

In termen van Lévi-Strauss: er is geen normerende mythe, geen centrum van de taal, geen absoluut begin of absolute eenheid. In termen van Derrida: iedere discours kan als referentiepunt worden genomen, maar het zou niet minder dan geweld betekenen om dat punt als typisch, dat wil zeggen ijkend, centrum te kiezen. Iedere structuur is radicaal a-centrisch. Toegepast op de casus waarmee dit artikel opent: het zou geforceerd ('gewelddadig') zijn om één van de rituele elementen waarmee de ritus gestructureerd is, bijvoorbeeld de klassiek-gereformeerde of de oecumenisch protestantse, als centrum waaraan de hele ritus geijkt wordt, te kiezen. Dat geldt dus ook voor de wetenschappelijke beschrijving ervan: daarin gaat het om de rite van de ritologie. Het liturgiewetenschappelijke discours kent geen centrum, geen liturgische ritus die het privilege heeft om als referentiepunt voor alle liturgische ritualiteit te dienen, zomin als er een originele liturgische ritus is waar alle andere liturgische riten aan ontspringen.

Derrida voert dan een gesprek met het empirisme, in de wetenschap dat Lévi-Strauss nooit uitspraken doet zonder dat die op empirisch onderzoek zijn gebaseerd. Uitspraken zijn niet in die zin altijd voorlopig omdat het veld nooit geheel en uitputtend is onderzocht, maar op grond van taal:

[T]he nature of the field - that is, language and a finite language - excludes totalization. This field is in fact that of play, that is to say, a field of infinite substitutions only because it is finite (Derrida 1967:423 = idem 1978:289).

Derrida keert het empirisch denken om: hij spreekt niet van een oneindig veld (dat nog maar beperkt is onderzocht), maar van een eindig veld, dat een oneindig aantal veronderstellingen toelaat omdat er geen centrum is dat het vrije spel van interpretaties fixeert en beëindigt. Evenmin is er een centrum dat van buiten aan het discours kan worden toegevoegd. 
De casus die dit artikel opent, is een eindig veld dat op oneindig veel manieren beschreven en geïnterpreteerd kan worden. Als de geprefereerde referentie aan één van de traditionele liturgisch-rituele modellen wordt losgelaten, opent zich een eindeloze reeks van mogelijke interpretaties. Wanneer deze referenties zijn losgelaten, opent zich als vanzelf de mogelijkheid ook andere referenties te laten varen, bijvoorbeeld die aan kerk of christelijk geloof. Er is - daar dienen we ook als theologen nuchter in te zijn - de mogelijkheid om kerkdiensten te beschrijven en dus interpreteren in termen van algemene ritualiteit, als verschijnsel van een locale, regionale of mondiale cultuur, of in termen van een algemene antropologie. Deze interpretaties zijn niet voorlopig in de zin van onvolledig, maar in de zin van open voor altijd weer nieuwe interpretaties. De casus kan, om een paar mogelijkheden te noemen, als een uitgebreid familiefeest beschreven worden, als feest van deze nieuwe dominee, maar ook denkbaar zijn beschrijvingen vanuit het perspectief van kerkgangers, maar evengoed vanuit de notie van de locale, landelijke of mondiale kerk. Het punt is evenwel, dat welke keuze ook gemaakt wordt, deze altijd a-centrisch is, en dat elke interpretatieve mogelijkheid weer eindeloos veel nieuwe interpretaties toelaat, maar bovenal ook, dat de verschillende vertogen niet tot elkaar zijn te herleiden: er bestaat geen overkoepelende algemenere taal die meerdere of alle discoursen omvat.

Aan het slot van zijn betoog gaat Derrida in op twee noties waarmee dit denken over bricolage op gespannen voet staat: geschiedenis en presentie. Deze spanningen beheersen het veld van de geesteswetenschappen.

Het denken vanuit structuren plaatst transformaties en wordingsgeschiedenis tussen haakjes. Lévi-Strauss geeft "structurality, (...) the internal originality of the structure" (Derrida 1967:425v. = idem 1978:291) voorrang, zegt Derrida, en plaatst tijd en geschiedenis tussen haakjes. Deze werkwijze heeft, nog steeds volgens Derrida, de voorkeur, om te voorkomen dat een moment in de geschiedenis centraal wordt gesteld (in onze casus bijvoorbeeld de periode van de vroege kerk of de reformatie, waarop respectievelijke liturgische stromingen zich beroepen). Liturgen en liturgisten wijzen dikwijls wel degelijk centrale momenten in de kerkgeschiedenis aan. De beroemde discussie tussen Noordmans en Van der Leeuw ging onder meer over de vraag of de tijd van de 
gereformeerde reformatie (zo Noordmans) of de gehele kerkgeschiedenis, maar met een accent op de vroege kerk (zo Van der Leeuw) het centrum van alle denken over liturgie moest vormen (Barnard 2004b). Toen ik vorig jaar onder de titel Liturgie voorbij de Liturgische Beweging een boek publiceerde waarin ik verschillende kerkdiensten op een min of meer a-centrische manier observeerde en beschreef, kwam mij dat op felle kritiek met name van adepten van de Liturgische Beweging te staan (Barnard 2006:9). In het maatschappelijk debat wordt, vooral tegenover mensen uit islamitische landen, de centrale positie van de Verlichting voor het westerse vertoog opgeëist.

Derrida wijst binnen het bricolagediscours ook een spanning aan tussen vrij spel en presentie. $\mathrm{Er}$ is alleen een gebroken onmiddellijkheid tot de oorspronkelijke bron, in onze casus tot de reformatorische, oecumenische, vroeg-kerkelijke of andere bronnen, of zelfs ook tot de oorspronkelijke bronnen van het christelijk geloof: tot de bijbel of God zelf. Het spel kent geen zekeringen ten aanzien van deze presentie. Een en ander betekent een volledige herformulering van bijvoorbeeld de sacramentsleer (zoals bijvoorbeeld Chauvet 1995). In het kader van dit artikel ga ik daar niet verder op in.

Derrida eindigt met een citaat waarin hij zegt dat "freeplay" de geboorte van een nieuwe "yet unnameable" voorbij-de-mens als metafysisch wezen aankondigt. Vrij spel verhindert het zoeken naar een centrale bron, een onmiddellijke presentie. De voorbij-de-mens geeft zich over aan het vrije spel van "interpretation of interpretation”. Hij

is no longer turned toward the origin, affirms play and tries to pass beyond man and humanism, the name of man being the name of that being who, throughout the history of metaphysics or of ontotheology - in other words, throughout this entire history - has dreamed of full presence, the reassuring foundation, the origin and the end of play (Derrida 1967:427 = idem 1978:292).

Deze nog onnoembare voorbij-de-mens laat zich, zegt Derrida, alleen in negatieve beelden denken: als niet-soort, vormloos, stom, kind of, zelfs, als angstwekkende monstruositeit... 


\section{NOG EENS DE CASUS: LITURGIE ALS ONGEORDENDE ORDE}

Ik heb mij lange tijd verbaasd over het gemak waarmee in veel kerkelijke gemeenten verschillende stijlen van eredienst worden gemixt. Enigszins gekscherend heb ik een eigentijdse kerkdienst wel eens gekenschetst als een gerecht met een aantal decibellen praise en een handjevol Liedboek, gekruid met een snufje Oosterhuis, een biologische Ionasong, en een eetlepel verstilling à la Taizé, geserveerd op een bedje van klassiek-gereformeerde en oecumenisch-protestantse hutspot, voor de fijnproevers afgemaakt met een toefje Bach. Ik verbaasde mij, en ergerde mij ook, - een ervaring die ik niet in de laatste plaats deelde met predikanten en kerkmusici, die zich thuis voelden bij één van de aan de bricolages ten grondslag liggende tradities, en zich niet in staat achten in andere als voorganger te functioneren. De gemeente bleek, anders en dikwijls eerder dan deze predikanten en musici, en ook anders en eerder dan ik, a-centrisch, a-origineel, a-typisch te denken. Predikanten en musici dachten zichzelf nog als voorhoede, als elite die de gemeente kon opvoeden; zij beschouwden zichzelf nog als leiders in het beschavingsoffensief dat de Liturgische Beweging gedurende de twintigste eeuw (ook) wilde zijn, of als de geestelijke voorhoede van de klassiek-gereformeerde theologie en liturgie.

Inmiddels blijken we dus in Nederland èn in Zuid Afrika want daar had ik met gemak een vergelijkbare casus kunnen kiezen - een generatie predikanten te hebben opgeleid die, min of meer voorzichtig, ook a-centrisch, a-origineel en a-typisch denkt, en die met vrijmoedigheid een vrij ritueel-liturgisch spel speelt. Een type predikant met andere woorden, dat er in slaagt de nieuwe mens die Derrida alleen in (soms verschrikkelijke) negatieve termen kan beschrijven, te bedienen. De nieuw bevestigde predikant stelt zich in de casus bij dit artikel niet op als de klassiek geschoolde gevuld is met uit allerhande tradities verzameld ritueel-symbolisch materiaal, een bricolageliturgie. Die bricolageliturgie verschijnt na de klassiekgereformeerde, de oecumenisch-protestantse en de praise-andworship liturgie niet als een vierde categorie - de notie categorie zou al boven- en onderschikking impliceren en dus het academicus, maar als de laatmoderne academicus-bricoleur die beseft te participeren in een zelfde discours als de overige gemeenteleden. Met andere woorden, die ook het academisch discours niet lokaliseert in het centrum maar als a-centrisch beschouwt. Deze academicus-bricoleur 
creëert met een zeker gemak uit een gereedschapskist die vrije spel alweer limiteren - maar als een locale en momentane vormeloze vorm, een ongeordende orde, een spel zonder spelregels. Anders gezegd, de liturgie wordt niet als expressie van een traditie, van zo men wil een bepaalde leer, maar als verhaal en als verbeelding opgevat, die in deze specifieke locale en temporele context moeten worden geactiveerd en geactualiseerd. Ik kom straks nog terug op welk verhaal en welke verbeelding hier in het vrije spel worden gebracht.

\section{LITURGIEWETENSCHAP, ETNOGRAFIE EN TAAL}

Ik begon dit artikel met een casus en refereerde aan vier tendensen in eigentijdse liturgie die ik eerder in een lezing in Pretoria signaleerde. Ik voegde daar een vijfde aan toe, de tendens liturgie vorm te geven door middel van bricolage. Ik herijkte dat veelgebruikte begrip door Lévi-Strauss en Derrida te herlezen en hun analyse van het begrip op de casus toe te passen. Lévi-Strauss spreekt van het mytho-poëtische karakter van zijn intellectuele reflectie op mythen. Derrida radicaliseert dat door ieder wetenschappelijk discours als vrij spel te benoemen, als spel van interpretaties van interpretaties. Binnen de wetenschapsleer, de antropologie en de liturgiewetenschap hebben die opvattingen meer of minder expliciet weerklank gevonden. In de nu volgende paragraaf plaats ik het aldus herijkte begrip in het geheel van de eigentijdse liturgiewetenschap.

We hoorden Lévi-Strauss zeggen dat het mythische denken een bricolage-achtige structuur heeft, en dat bricolage mytho-poëtisch van aard is. Derrida draait dat om en radicaliseert dat door te zeggen dat ieder discours een bricolage karakter heeft en dus mythopoëtisch is. De antropoloog Roy Rappaport karakteriseert de rite primair als taal - niet alleen een verbale taal, maar ook een taal die uitgedrukt wordt in handelingen en met voorwerpen. In navolging van Peirce en Buchler ziet hij taal als een samenstel van lexiconsvan-symbolen en grammatica's. Preciezer geformuleerd, taal bestaat uit

"lexicons made up of symbols: signs only related to what they signify 'by law', i.e. convention”, en "grammars, sets of rules for combining symbols into semantically unbounded discourse” (Rappaport 1999:4).

De rol van religie, zegt Rappaport, is om bepaalde ijkpunten binnen het eindeloze interpretatienetwerk van die talen te vestigen - "the 
true Word" - waarop andere "waarheden” gevestigd worden (Rappaport 1999:passim, hier 21). Derrida zou dit geforceerd vinden, en opmerken dat het discours geen centrum heeft, en dat er ook geen extern centrum buiten het discours kan worden geclaimd. Wel erkent hij dat wie signifier (signans, signifiant) en signified (signatum, signifié) bijeen wil houden, een dergelijke toevoeging nodig heeft. Anders gezegd, hij erkent, met Lévi-Strauss, wel degelijk dat in vele discoursen waarheidsclaims worden geëist (Derrida 1967:423v. = idem 1978:289). De rol die Rappaport aan de religie toekent, geldt tenminste in het westerse christendom maar in beperkte mate. Van een stabiel religieus betekenisnetwerk is daar immers nauwelijks meer sprake, zelfs niet in één gemeenschap, getuige de in de casus beschreven bricolageliturgie. Binnen de beschreven dienst kan Jezus Christus als een dergelijk "true Word" worden beschouwd. Ik kom daar nog op terug in de slotparagraaf van dit artikel. Samenvattend, taal, dus ritualiteit, beweegt zich bij Rappaport in een vrij discours dat eindeloze ketens van betekenissen opent. Alleen conventie en religie kunnen daar enige orde in scheppen: een teken betekent nu eenmaal iets, en religie kan "ware" betekenissen vestigen.

De wetenschapsantropoloog Bruno Latour brengt religie en kunst (en dus ook liturgie en ritualiteit) èn de reflectie op beide op het niveau van de verbeelding. Ook hier speelt de mytho-poëzie dus een voorname rol. Ik acht de these die hij onder de naam "iconoclash" heeft gepubliceerd voor het liturgiewetenschappelijk discours van belang (Latour 2002). De these van Latour refereert aan Lévi-Strauss' karakterisering van het etnografisch vertoog als mytho-poëtisch, en Derrida's kenschetsing van ieder geesteswetenschappelijk discours als vrij spel van interpretaties. Net als Derrida acht Latour "waarheid” principieel niet bereikbaar. Hij spreekt in dit verband van ambivalenties. Religie, kunst en wetenschap behoeven alle de bemiddeling van het beeld, en hebben tegelijkertijd een ambivalente verhouding tot het beeld gemeen. De vraag kan niet opgelost worden of het beeld uitdrukking van (objectieve) waarheid is of menselijk construct ("showing the hands of humans at work" [Latour 2002:16]), realiteit of constructie, werkelijkheid of menselijk product. Die ambivalentie drukt Latour uit met een neologisme, de notie iconoclash. Religie, wetenschap en kunst zijn volgens Latour daarin gelijk, dat zij alle de bemiddeling van het beeld nodig hebben. De vraag naar wat waarheid is, kan niet 
beantwoord worden zonder beelden en tegelijkertijd zijn die beelden de waarheid niet. Latour is minder vrijblijvend dan Derrida omdat hij over de waarheid blijft spreken, maar net als bij Derrida is die onbereikbaar en alleen in niet te fixeren beelden te benaderen. Daarbij is beeld in zijn denken een breed begrip; het omvat niet alleen het plastische beeld, maar ook schrift, ritus, muziek, woord, statistiek, concepten, afbeeldingen, beschrijvingen, - kortom al die expressies die de waarheid claimen te benaderen in de domeinen van kunst, wetenschap en geloof, zonder die waarheid zelf te zijn. 'Beeld' omvat de hele cultuur. Met betrekking tot de casus in dit artikel is beeld liturgische-ritualiteit. Latour wil de ambivalentie te boven komen en stelt voor het tweede gebod voorlopig te herformuleren als: "Thou shall not freeze-frame any graven image" (Latour 2002:37). De bemiddeling van het beeld is noodzakelijk, in kunst, wetenschap en religie. Maar het beeld moet noch voor de waarheid zelf worden aangezien, noch moet zijn noodzaak worden ontkend.

Sterk aan Latour verwant zijn de opvattingen die de bekende ritendeskundige Ronald Grimes in 2006 bij zijn oratie als bijzonder hoogleraar aan de Radbout Universiteit in Nijmegen uitsprak (Grimes 2006:11-15). Zoals Latour het beeld naar voren bracht als gemeenschappelijk aan religie, kunst en wetenschap, zo is bij Grimes performance de centrale notie. Ritualisatie ("ritualizing") en academische rituele theorie zijn afhankelijk van verbeelding, metaforen, narratieven en performances. Deze performance bestaat er aan de academie in dat - 'ceremonieel' - theorie macht uitoefent, academische waarden bewaakt en geld genereert, en - 'magisch' rituelen worden omgezet in gegevens, data, theorie. "Like painting and storytelling, theorizing is an art engaged in by people who are both enculturated and embodied” (Grimes 2006:13; Barnard 2007b). Hiermee verklaart Grimes zich impliciet schatplichtig aan het bricolagebegrip van Lévi-Strauss en Derrida: rituele theorievorming participeert in het proces van ritenvorming. Taal is bij Grimes, evenals bij Rappaport, breder dan woorden, en hij spreekt van performance dat het inbegrip van (symbool)taal, (symbool)handeling en symbool is.

$\mathrm{Al}$ deze theorieën maken duidelijk dat liturgie allereerst in zijn talige structuur moet worden onderzocht en begrepen. De beschrijving en analyse ervan - zeker, op grond van empirische waarneming, maar zonder in een reductionistisch of positivistisch 
empirisme te vervallen - is, op grond van het feit dat ieder discours een bricolagekarakter heeft, zelf ook weer op vele manieren te interpreteren. Er is geen finale beschrijving of een laatste analyse van de liturgie mogelijk.

Met betrekking tot onze casus zijn de in dit artikel beschreven theorieën ook theologisch toe te passen. Liturgie mag geen fixatie worden, maar moet zich vrij bewegen ten opzichte van de geloofde en beleden waarheid die in een stroom van niet te fixeren beelden benaderd wordt. Ik merk op, dat dit in de leer van de reformatoren een aangelegen punt is. Wat niet wil zeggen dat in de praktijk ook de protestantse liturgie niet steeds weer is gefixeerd, om niet te zeggen versteend. Luther heeft uitgerekend in zijn klassieke geschrift over de vrijheid (namelijk in het slothoofdstuk van de Latijnse versie) ook de vrijheid van de liturgie bepleit (Luther 69-73). Onmiddellijke presentie en een centrale normatieve historische periode hebben zij afgewezen onder verwijzing naar de meest ongrijpbare persoon van de Triniteit, de Geest. Practices of Faith kunnen niet worden vereenzelvigd met God of gezekerd worden in een specifieke theologie of editio typica van de liturgie. Het ritueel-liturgisch discours is bricolair van karakter en is samengesteld uit wat toevallig voorhanden is. Het is geen ingenieurswerk dat totalitaire aanspraak kan doen: de liturgie is niet goddelijk. Om die reden participeren de liturgiewetenschap en de praktische theologie in het geesteswetenschappelijke discours, al nemen zij ook aan het theologisch vertoog deel, namelijk wanneer zij hun particuliere vertrekpunt nemen in het ware Woord. Daarover handelt de slotparagraaf van dit artikel, waarin ik nog eenmaal terugkeer naar de casus.

\section{NOG EENMAAL DE CASUS: CHRISTUS ALS A- CENTRISCHE PARTICULARITEIT}

Als in lied, gebed, bevestiging en preek in de beschreven kerkdienst één ding onmiddellijk evident was, dan wel dat dit een christelijke eredienst was. Zonder gene en aarzeling werd de naam van Christus genoemd, aanbeden, verkondigd en aangeroepen. Anders gezegd, de dienst nam een specifiek vertrekpunt en wortelde daar stevig in, namelijk in het christelijk getuigenis. Dit gebeurde in het radicale besef van het a-centrische ervan in deze geseculariseerde context (dit a-centrische werd nadrukkelijk verwoord door de net bevestigde 
predikant in haar intredepreek). Het is niettemin die christelijke particulariteit die frank en vrij wordt geactiveerd en geactualiseerd.

Hier neem ik een markant verschil met een vorige generatie geestelijke leiders in de kerk waar: die was òf veelmeer bezig om het particuliere onder het algemene te subsumeren, probeerde met andere woorden (bepaalde vormen van) christelijk geloof onder veel algemenere noemers te brengen zoals religiositeit en zingeving, òf stelde de eigen particulariteit radicaal centraal en sloot daarmee iedere andere particulariteit buiten.

Concreet, er wordt weer (of nog) vrijmoedig over Jezus Christus en de Heilige Geest gesproken, maar tegelijkertijd wordt volledig verdisconteerd dat dat binnen de context van de geseculariseerde samenleving een a-centrisch en a-typische keuze is. Steeds is er het besef dat anderen hun particulariteiten (of eigenaardigheden) hebben. Er wordt niet meer voorzichtig bij de gevoelens van mensen ingezet om tenslotte ook nog een enkel woord aan Jezus van Nazareth te wijden, noch ook wordt de eredienst opgebouwd volgens strak klassiek-gereformeerde of oecumenischprotestantse ('Liturgische Beweging') schema's die beide Christocentrisch waren. Het verhaal van Jezus Christus wordt in de casus integendeel in zijn eigen a-centrische particulariteit ritueelsymbolisch geactiveerd en geactualiseerd binnen de specifieke context van deze gemeente op dit moment. Jezus Christus is met andere woorden binnen het geheel van deze ritus het gekozen vertrekpunt van waaruit de hele ritus 'leesbaar' wordt, zonder dat de op gang gebrachte betekenisstroom wordt ingedamd of beperkt. De activering en actualisering van het verhaal van Jezus Christus krijgen vorm zonder verwijzing naar een specifiek centrum, een typisch ijkpunt of een absoluut origineel, een editio typica. Niet de voorgegeven, de voorgevormde betekenissen tellen, maar de stroom van steeds nieuwe betekenissen die door de a-typische vorm van deze eredienst op gang komt. Liturgie is hier, kortom, vrij christelijk spel: bricolageliturgie.

\section{Literatuurverwysings}

Barnard, M 2001. Prinses Diana als postmoderne heilige en een kerkdienst in een museum. Tendensen in de dynamiek van cultus en cultuur vanuit een West-Europees perspectief. Verbum et Ecclesia 22(2), 209-230.

-, 2002. Tendensen in de dynamiek van cultus en cultuur. Perspectieven in de liturgiewetenschap in: Barnard, M \& Schuman, $\mathrm{N}$ (reds.) Nieuwe wegen in 
de liturgie. De weg van de liturgie - een vervolg. Zoetermeer: Meineima 1127.

-, 2004a. De dans kan niet sterven. Gerardus van der Leeuw (1890 - 1950) herlezen. Zoetermeer: Meineima (Prof. Dr G. van der Leeuw-stichting, Onderbreking 3).

-, 2004b. Liturgia semper reformanda quia ecclesia reformata. Het gebruik van tradities in recente protestantse liturgiehervormingen. Jaarboek voor liturgie-onderzoek 20, 59-72.

-, 2006. Liturgie voorbij de Liturgische Beweging. Over 'Praise and Worship', Thomasvieringen, kerkdiensten in migrantenkerken en ritualiteit op het internet. Zoetermeer: Meineima.

-, 2007a. Einsegnung in das geistliche Amt in der vereinigte reformierten und lutherischen Kirche in den Niederländen in: Mildenberger, I (red.), Ordinationsverständnis und Ordinationsliturgien. Ökumenische Einblicke 101-115. Leipzig: Evangelische Verlagsanstalt (Beiträge zu Liturgie und Spiritualität).

-, 2007b. Naar een nieuwe protestantse avondmaalstheologie. Een reconstructie aan de hand van Rappaports "great inversion”, Jaarboek voor Liturgieonderzoek 23, 7-23.

Chauvet, L-M 1995. Symbol and Sacrament. A Sacramental Reinterpretation of Christian Existence (= Symbole et Sacrament. Un relecture sacramentelle de l'existence chrétienne, 1987). Collegeville: Liturgical Press.

Derrida, J 1967. La structure, le signe et le jeu dans le discourse des sciences humaines in: Derrida, J (ed.) L'écriture et la difference, s.l., 409-428 (= Derrida, Jacques, 1978, 'Structure, Sign, and Play in the Discourse of the Human Sciences', in Writing and Difference, Chicago, 278-293).

Dienstboek, een proeve. II. Leven, zegen, gemeenschap. Zoetermeer: Boekencentrum. 2004.

Grimes, R 2000. Deeply into the Bone. Re-inventing Rites of Passage. Berkeley: University of California Press.

Grimes, R 2006. Re-imagining ritual theory. John Bourke among the Hopis (= oratie Nijmegen). Nijmegen.

Hofstee, W 1991. Gerardus van der Leeuw and the Concept of Primitive Mentality, Knippenberg, H G \& Luchesi, B (reds.), 127-137. Religionswissenschaft und Kulturkritik. Marburg: Diagonal Verlag.

Hofstee, W 1997. Goden en mensen. De godsdienstwetenschap van Gerardus van der Leeuw. Kampen: Kok Agora.

Hoondert, M J M 2006. Om de parochie. Ritueel-muzikale bewegingen in de marge van de parochie. Gregoriaans, Taizé, Jongerenkoren (= dissertatie Tilburg). Heeswijk. 
Latour, B 2002. What is Iconoclash? Or is There a World Beyond the Image Wars? In: Latour, B \& Weibel, P (eds.), Iconoclash. Beyond the Image Wars in Science, Religion and Art, 14-37. Karlsruhe: MIT Press.

Lekkerkerker, A F N 1956. Kanttekeningen bij het hervormde dienstboek: dl. II. Den Haag.

Lévi-Strauss, C 1962. La Pensée Sauvage. Paris: Librairie Plon (= LéviStrauss, C 1972. The Savage Mind. London: Weidenfeld \& Nicolson).

Luther, M Von der Freitheit eines Christenmenschen. Slothoofdstuk, WA 7, 6973.

Post, P 2007. A Symbolic bridge between faiths. Holy ground voor vloeibaar ritueel in Jaarboek voor Liturgieonderzoek 23, 71-101.

Rappaport, R 1999. Ritual and Religion in the Making of Humanity. Cambridge: Cambridge University Press (Cambridge Studies in Social and Cultural Anthropology, 110).

Van der Leeuw, G 1937. De primitieve mensch en de religie. Groningen: Wolters. 